\title{
Parliamentary Reform
}

La réforme du Parlement

\section{Philip Norton}

\section{(2) OpenEdition}

\section{Journals}

Electronic version

URL: http://journals.openedition.org/rfcb/696

DOI: $10.4000 / \mathrm{rfcb} .696$

ISSN: 2429-4373

\section{Publisher}

CRECIB - Centre de recherche et d'études en civilisation britannique

\section{Printed version}

Date of publication: 1 February 2002

Number of pages: 18-30

ISBN: 2-911580-13-3

ISSN: 0248-9015

\section{Electronic reference}

Philip Norton, «Parliamentary Reform », Revue Française de Civilisation Britannique [Online], XI-3 | 2002, Online since 21 March 2016, connection on 19 April 2019. URL : http://journals.openedition.org/ rfcb/696; DOI : 10.4000/rfcb.696

This text was automatically generated on 19 April 2019

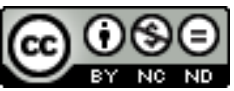

Revue française de civilisation britannique est mis à disposition selon les termes de la licence Creative Commons Attribution - Pas d'Utilisation Commerciale - Pas de Modification 4.0 International. 


\title{
Parliamentary Reform
}

\author{
La réforme du Parlement
}

\section{Philip Norton}

The British Parliament constitutes what Michael Mezey has characterised as a reactive, or what I have termed a policy-influencing, legislature. ${ }^{1}$ Policy is formulated and proposed by the executive. Parliament discusses the policy and gives (or withholds) its assent to it. This relationship of Parliament to the executive is historically well entrenched. Originally, it was the monarch who was the fount of public policy, now it is the body of the monarch's principal ministers meeting in Cabinet. The basic relationship has not been a matter of fundamental dispute in recent decades. What has been a matter of dispute is the extent to which Parliament, in responding to the executive, could influence and constrain it. Jean Blondel coined the term 'viscosity' to refer to a legislature's capacity to slow the stream of executive actions and proposals. ${ }^{2}$ Critics have variously regarded Parliament in the UK as having a low viscosity, both in absolute terms and relative to many West European legislatures.

2 Demands for reform have generally focused on strengthening the viscosity of Parliament. They have rarely been aimed at changing fundamentally the relationship between the executive and legislature, that is, in terms of creating a policy-making rather than a policy-influencing legislature. Occasionally a writer advocates a system of separation of powers but such advocacy is exceptional. Most critics offer prescriptions for a stronger policy-influencing legislature.

3 Calls for parliamentary reform can be seen in cyclical terms. Perceptions of a weak Parliament, especially in the face of an ever more powerful executive, build up. There are demands for reform. The government resists these demands but eventually some concession is made and various changes occur in parliamentary structures and procedure. There is then a period of consolidation (some might say of complacency) before perceptions of Parliament still being weak in relation to a powerful executive build up and demands for reform follow.

4 There was a build up of demands for reform in the 1960s, resulting in various changes - to committees and procedures - under the Labour Leader of the House of Commons, Richard 
Crossman. The reforms themselves had a limited effect and demands for change were renewed in the 1970s. They resulted in the most significant change of the past fifty years with the introduction, in 1979, of a series of investigative select committees to cover most (since extended to all) government departments. They were introduced at the beginning of a new Parliament under the Conservative Leader of the House, Norman St.John-Stevas. Various other changes were also made in that Parliament. Dissatisfaction built up again, especially in the 1990s. The incoming Labour Government in 1997, under Prime Minister Tony Blair, was committed to some reform of Parliament. Some changes were implemented but, as we shall see, they were limited. They failed to satisfy the demands of those seeking to strengthen Parliament as a policy-influencing legislature.

5 The calls for reform can themselves be grouped now under two headings. There are those seeking reform of Parliament through change external to the institution. Advocates of such reform believe that Parliament will only be able to play a significant role in the political process if there is constitutional reform. They support, in particular, the introduction of a new electoral system to prevent the likelihood of the election of a single-party majority government. Calls for a new electoral system were made in the 1970s but have been more vocal and more strident in recent years. The Liberal Democrats are long-standing supporters of electoral reform. The Labour Party in the 1990s was also more sympathetic than before to reform. In its election manifesto in 1997 the party proposed establishing a commission and then holding a referendum on the subject. An Independent Commission on the Voting System, set up in 1997 by the Prime Minister, reported in 1998 and recommended a new, and novel, electoral system (the Alternative Vote Plus) for parliamentary elections. However, no action was taken on the Commission's report in the Parliament and the Labour Party manifesto in the 2001 general election committed the party only to a review of the report.

There are also demands for reform internal to the institution. These have been at the heart of demands for parliamentary reform over the decades and generally bring together a wider range of supporters than demands for external reform. (The two are not mutually exclusive, with some advocating both external and internal reform, but not all those favouring internal reform support external reform.) The calls for internal reform include the creation and strengthening of committees, the overhaul of the process for scrutinising legislation, changes in procedures for holding debates and Question Time, new methods of appointing members to committees, and more extensive resources for members.

7 The demands for reform outlined so far have focused on the elected chamber, the House of Commons. There have also been demands for reform of the second chamber, the unelected House of Lords. These can also be characterised under the headings of external and internal reform. External reform takes the form of statutory change designed to transform the chamber in terms of composition and/or powers. Internal reform is designed to enable the House to use more effectively the powers that it already has. The House of Lords is a self-regulating body - there is no presiding officer exercising any independent powers - and has proved more willing than the House of Commons to engage in reflective study of its own practices and procedures and to modify them from time to time. Such changes have not been the focus of public pressure or attention. Instead, most debate about the Upper House has concentrated, almost exclusively, on composition and the place of the House in the political process. 
This brief prologue sets the scene for an analysis of reform under the Labour Government elected in 1997. I address five questions about reform of the House of Commons. First, why the need for reform? Second, what reform has been implemented under the Labour Government of Tony Blair? Third, why has the reform not been more extensive? Fourth, what reform proposals are presently on the agenda? And, finally, what are the prospects of further reform being achieved? I address similar questions, but - for reasons of space in a shorter section, for the House of Lords.

\section{Why the Need for Reform?}

9 In the view of many commentators, the House of Commons is a relatively weak policyinfluencing legislature and one that is getting weaker. Why? In July 2000, the Commission to Strengthen Parliament published its report, Strengthening Parliament. ${ }^{3}$ The Commission was established in July 1999 by the Leader of the Opposition, William Hague, "to examine the causes of the decline in the effectiveness of Parliament in holding the executive to account, and to make proposals for strengthening democratic control over the Government". I chaired the Commission and it took evidence from informed witnesses drawn from several political parties and from none. I focus here on its analysis of 'decline'.

Decline denotes a fall from some higher point. The Commission rejected the notion that there had been a 'golden age' of Parliament. Nonetheless, it did accept that there had been several developments, often independent of one another and occurring at different times, which had served to weaken Parliament in challenging the executive. It identified three long-term developments and a number of more recent ones. The long-term developments were:

- the growth of party, ensuring an aggregation of views, the growth of party loyalty and cohesion (both outside and inside Parliament), and normally providing the government with a party majority to carry its measures;

- the growth of government business, both in quantity (the volume of legislation) and quality (the complexity of legislation), creating a massive burden of business to be transacted by Parliament; and

- the growth of organised interests, with information and sanctions (withdrawal of co-operation) at their disposal, both of which a party-dominated House of Commons lacked or was unwilling to employ.

These have been compounded by more recent developments:

- partisanship, creating a sharp clash between parties and a greater negativism in debate;

- the rise of the career politician, creating an increase in consumption of parliamentary resources and squeezing out of the institution people with experience of sectors other than politics;

- concentration of power in Downing Street, with the Prime Minister becoming more 'presidential' and hence detached from his own party and government as well as from Parliament;

- constitutional change, with law-making powers being passed to other institutions, such as the institutions of the European Union and elected assemblies in different parts of the UK;

- the media revolution, with 24-hours news and a government capacity to exploit the developments that cannot be matched by Parliament; and

- de-politicisation with some elements in society opting for direct action rather than debate and also with some issues being hived off to non-elected bodies. 
There are two essential points arising from the Commission's analysis. First, there is no single development that accounts for the limited viscosity of the House of Commons. Second, these developments are, in many cases, irreversible. Consequently, if Parliament is to be strengthened in calling the executive to account, one has to look beyond the developments themselves.

\section{What Reform has been Implemented?}

13 The Labour Party manifesto for the 1997 general election said that "the House of Commons is in need of modernisation" and promised that a Labour government would ask the House of Commons to set up a special committee to review its procedures. It went on: "Prime Minister's Questions will be made more effective. Ministerial accountability will be reviewed so as to remove abuses. The process for scrutinising European legislation will be overhauled". ${ }^{4}$

As soon as Labour took office, the new Prime Minister, Tony Blair, decided to answer questions during one thirty-minute slot each week in the House of Commons rather than two fifteen-minute slots. The House of Commons agreed to the creation of a Select Committee on the Modernisation of the House of Commons. As is usual with committees, the membership reflected proportionately the party composition of the House as a whole: unusually, though, it was chaired by a minister (the Leader of the House) and not a backbencher. It was given the task "to consider how the practices and procedures of the House should be modernised, and to make recommendations thereon." It was asked to make its first report on ways in which "the procedure for examining legislation could be improved" and to do so before the summer recess. Seven weeks after it was appointed, it published its report, entitled The Legislative Process. ${ }^{5}$

report proposed a wide range of reforms, mostly to be undertaken on an experimental basis. These included programming the passage of legislation (stipulating the times at which particular stages had to be completed), greater pre-legislative scrutiny and consultation, and provision for some bills to carry over from one parliamentary year to another. The report was approved by the House of Commons and several of the recommendations put into effect. Programming motions were introduced for bills, a number of bills were published in draft form and one major bill was carried over from one session to another.

The Select Committee on Modernisation went on to publish reports on a wide range of issues. By the end of the Parliament, it had published seventeen reports. Of these, eight were published in the first parliamentary session (1997-98) of its existence. It issued reports on such matters as the scrutiny of European legislation, voting methods, the creation of a 'parallel chamber', facilities for the media, and the timing of votes. A number of its recommendations were implemented. Provision for the scrutiny of European legislation was extended: the second and third pillars of the European Union were brought within the ambit of scrutiny. A new parallel chamber was created, with sittings (open to all MPs) being held in the Grand Committee Room, just off Westminster Hall and known formally as 'sittings in Westminster Hall'. Sittings in Westminster Hall enabled Members to raise issues of concern to them, but with no provision for votes to take place. Some improvements were made in facilities for the media, including more space to carry out televised interviews. There was also a change in voting procedure, with certain specified topics debated late at night being voted on by paper ballot (a novel 
departure for the House) on a Wednesday afternoon. The Committee also explored whether voting should also take place electronically, but most Members preferred to stick with the existing practice of voting physically in a division lobby.

By the end of the Parliament in 2001, the House of Commons was operating under a number of new procedures. Some had strengthened the House in its capacity to call government to account. When the House of Commons debated parliamentary reform in July 2000, Tony Blair said: "We have taken major steps... to improve the ways in which the House can work." Critics, however, took a different view, arguing that some reforms favoured government in getting its business (notably programming and holding over some votes until Wednesday afternoon) and that the government had failed to implement other reforms that had been proposed to strengthen the House of Commons. The Liaison Committee of the House, comprising the chairmen of select committees, had recommended changes designed to make committee service more attractive to MPs. The government rejected the committee's recommendations, even though the committee had a majority of government supporters sitting on it. The committee criticised the government's stance. The opposition, perhaps not surprisingly, attacked the government for neglecting Parliament. So too did various parliamentary experts and journalists. "The Blair government", wrote Peter Riddell, the respected columnist for The Times, "has neglected Parliament".

\section{Why has Reform not been more Extensive?}

18 The period since 1997 has thus seen changes to procedures in the House of Commons. However, they are best described as modest changes. Little has happened that has significantly strengthened the capacity of the House of Commons to constrain the executive. Why, then, has reform not been more extensive?

One explanation is intrinsic to a parliamentary system of government, especially one that normally has single-party majority government. Members of the majority party are returned as party members and, as such, wish to sustain their party in government. At the same time, as Members of Parliament, they are members of a body that is expected to subject that very same government to critical scrutiny. There is thus a potential conflict between loyalty to party and loyalty to the institution to which they have been elected. Self-interest normally determines that party wins in any such conflict. Pursuit of shortterm party interest, as exemplified by intense partisanship in the chamber, can be at the expense of public confidence in the House of Commons. The relevance of this for our purposes is that if the government wishes to resist reform, its supporters may be reluctant to oppose it. Party loyalty and ambition for office are powerful weapons in the hands of the government.

There are also features that have been particular to the Blair government. I have identified four, which I have characterised as uncertainty of purpose, the government's need to get its business, the absence of leadership, and commitment to constitutional change. ${ }^{8}$

21 Uncertainty of purpose. Reform of parliamentary structures and procedures can be carried out for a number of reasons. It may be carried out in order to expedite the passage of government business. It may be carried out for the convenience of Members, making parliamentary life less burdensome. It may be implemented for largely cosmetic 
purposes, removing practices that are difficult for members of the public (and sometimes Members) to understand. It may be carried out to enable Members to scrutinise and constrain government more effectively. A case may be made for each of these, but it is helpful to know the motivation of those bringing forward reform proposals. The problem with the reforms of the Blair government is that they have had no clear focus. They have been carried out as part of the government's process of 'modernisation', a term that covers everything and consequently means nothing. Some changes have been made for the convenience of Members (such as creating, in effect, a three-day parliamentary week). Some have been to the benefit of government, notably programming (ensuring government gets its business, with some very tight timetables imposed) and the carryover of some votes to Wednesdays. Some have been for the purpose of tidying up procedure that is difficult for the public to understand (such as the requirement to wear a hat when raising a point of order during a vote) and some have been to strengthen Parliament in calling government to account. Strengthening the House in calling government to account has not been the exclusive or even primary focus.

The government's need to get its business. Any government wants to get its business through the House of Commons. Some governments are keen to get it passed as quickly as possible. The Blair government was a new government. It had a legislative agenda it wished to implement. Tony Blair appointed as Chief Whip a man who had a reputation for firmness and who was committed to ensuring the government got its way. The government's need to get its business took precedence over any desire to strengthen the House of Commons in challenging what the government was doing. This was also the attitude taken by the person who, for most of the Parliament, was Leader of the House of Commons, Margaret Beckett. She resisted attempts to strengthen select committees and took what is best characterised as an executive-oriented approach. It was not an approach that endeared her to members of the Liaison Committee, who gave her a particularly difficult time when they summoned her to give evidence, but it was one that appeared to chime with her boss, the Prime Minister.

Absence of leadership. If major reform is to be achieved, there not only needs to be a coherent proposal for change there also needs to be leadership in order to bring it about. There was no such leadership under Tony Blair. Blair had little interest in the House of Commons. He spent little time there. The time devoted to the House by Prime Ministers has been declining for well over a hundred years. ${ }^{9}$ Blair spent less time there than his predecessors. Though turning up regularly for Prime Minister's Question Time, he rarely took part in any debates and he had a notably poor voting record, the worst of any modern Prime Minister. ${ }^{10} \mathrm{He}$ did not appear to regard Parliament as central to the task of government and he expected his MPs to be loyal to the government in whatever it decided to do. When the House debated parliamentary reform in July 2000, he attacked the Leader of the Opposition for choosing it as a topic of debate. "I do not know", he said, "whether people in his pubs and clubs are talking about pre-legislative scrutiny, but they are not in mine." constitutional questions". Reform of the House of Commons did not appear to come within the ambit of big constitutional questions.

Commitment to constitutional reform. The Labour government was committed to major constitutional change. It implemented legislation creating elected assemblies in Scotland, Wales and Northern Ireland, and it introduced an elected mayor for London. These changes received popular approval in referendums. It removed most hereditary peers 
from membership of the second chamber. It achieved passage of the Human Rights Act, incorporating the European Convention on Human Rights into British law. It achieved passage of a Freedom of Information Act. The constitutional landscape thus changed quite dramatically. These changes had two implications for the House of Commons. First, they meant that reform of the House of Commons was seen as of limited importance compared to the bigger changes being enacted. Second, the changes themselves had implications for Parliament. A whole sphere of decision-making was devolved from Parliament to elected assemblies in different parts of the UK. The enactment of the Human Rights Act strengthened the courts in relation to Parliament. Parliament thus faced a challenge in adapting to these changes as well as considering how it could strengthen itself in calling government to account. The pressure to act appeared greater than its capacity to respond.

These variables, in combination, explain why the House of Commons received more criticism for its failure to reform than it did praise for what change was implemented. Though there were some changes, they failed to keep pace with the pressures that were resulting in the further marginalisation of the House of Commons.

\section{What Reform Proposals are on the Agenda?}

Recognising that Parliament has been further marginalised in the political process, various bodies have published proposals for strengthening the House of Commons. These have included parliamentary bodies, notably the Liaison Committee. In March 2000, it published a report, Shifting the Balance: Select Committees and the Executive, arguing that committees should be strengthened, not least through creating a career structure as an alternative to ministerial office..$^{12}$ As we have noted already, the Leader of the Opposition, William Hague, set up a Commission to Strengthen Parliament in 1999, with the Commission reporting the following year. It made nearly ninety recommendations for change.$^{13}$ These included strengthening the chamber as a debating arena, strengthening select committees (paying chairmen, taking selection of members out of the hands of the parties), reforming standing committees dealing with legislation, improving scrutiny of financial legislation (including allowing select committees to recommend changes in the estimates) as well as of secondary and European legislation. It also wanted to strengthen the resources available to Members individually as well as provide training for them. It recommended making the House more accessible, both to the citizen and to the media. It also favoured constraining government, recommending fewer ministers, fixed dates for parliamentary sittings, and the Prime Minister appearing regularly before a committee. The report received favourable press comment. It was debated in the House of Commons on 13 July 2000 and in the House of Lords on 14 February 2001.

The report of the Commission to Strengthen Parliament was followed by a report from another commission. In 1999, the Hansard Society (a charitable body dedicated to promoting the cause of parliamentary government) appointed a Commission on Parliamentary Scrutiny. (The Society had, almost a decade before, established one on the legislative process, which published a substantial report on the subject.) ${ }^{14}$ The Commission, under the chairmanship of a former Leader of the House of Commons, Tony Newton (Lord Newton of Braintree), sat for two years and published its report in June 2001, just after the general election. Entitled The Challenge for Parliament: Making Government Accountable, the report contained almost fifty recommendations for change. ${ }^{15}$ 
It, too, favoured strengthening select committees, with committees having clear objectives and the power to appoint sub-committees, and with a closer link between committees and the floor of the House. It also wanted to see a strengthening of parliamentary scrutiny of finance and better communication with the public.

The proposals from these bodies tend to complement rather than compete with one another. There is a clear desire to strengthen the role of select committees and to enhance the role of the chamber. For reform to be effective there has to be a window of opportunity, a reform agenda, and leadership. There is clearly a reform agenda.

\section{What are the Prospects for the Futher Reform?}

The limitations of implementing a reform agenda have been well recognised by the Hansard Society Commission. It wrote, in one of its concluding paragraphs:

The Commission is well aware that parliamentary reform has traditionally been a slow process. The success of reforms often relies on balancing the aspirations and objectives of MPs and ministers, frontbenchers and backbenchers, Government and Opposition. Reform should, as far as possible, seek to meet the needs of these different groups. However, it has often been the case that the perceived difficulties of reform have prevented a creative and long-term approach to the role of Parliament. This has, in turn, lengthened the time it has taken to implement change. ${ }^{16}$

30 Is it likely to remain a slow process? A Labour government has been re-elected to office with a clear priority to implement reform of the public services. Parliamentary reform hardly figures in its agenda. In its manifesto for the 2001 general election, it committed itself to legislation to allow parties to make positive moves to increase the representation of women in Parliament. In addition, "Labour will continue to modernise the procedures of the House of Commons so it can effectively fulfil its functions of representation and scrutiny." ${ }^{17}$ That was the extent of the commitment. There was no mention of what 'modernisation' would involve in terms of specific changes. The party continues to be led by an executiveoriented Prime Minister who appears to have little time for the House of Commons. The Prime Minister heads a government with a large overall majority in the House of Commons. Even if a large number of Labour MPs disagrees with what the government is doing (or not doing), the government is still likely to emerge victorious in any vote.

The only change that has taken place that gives reformers some hope is the fact that there is a new Leader of the House of Commons. Former Foreign Secretary Robin Cook was appointed, following the general election, to replace Margaret Beckett. As Foreign Secretary, Cook was notably executive-oriented and clashed with the Select Committee on Foreign Affairs. His background, on the face of it, is not encouraging. However, his appointment as Leader of the House was widely seen as a demotion. There is therefore a belief among some commentators, and among parliamentary insiders, that he may wish to make a political mark by building a reputation as a reforming Leader of the House, rather than one who leaves no notable legacy.

Robin Cook's words since taking up his new position have tended to be encouraging. Speaking in the House of Commons on 27 June 2001, he said:

I hope that we will be able to build consensus on modernisation of the Commons. As Leader of the House, I shall seek support in all quarters for two important objectives to modernisation. The first is to enable the House to hold the Government to account and to scrutinise their Executive decisions and legislation. ${ }^{18}$ 
second objective was to get select committees appointed before the House rose for the summer recess. It had been assumed that the appointment was likely to be delayed until the Autumn. Cook announced that he planned to get them appointed in the week commencing 16 July. Also giving reformers hope of action was the fact that the junior minister appointed to support Cook was an MP who was a supporter of reform (Stephen Twigg). Cook appointed as his special adviser Greg Power, who had served as secretary to the Hansard Society Commission on Parliamentary Scrutiny. Cook was also known to favour extending the process of consultation on bills, bringing in people with expertise from outside to offer their opinions.

encouraging signs were off-set by the fact that Cook moved motions to change the Standing Orders of the House, providing for the timetabling of legislation. The revised Standing Orders were not seen by the Opposition as overly generous. It was also feared that, even if cook did bring forward proposals for major reform of the House in order to enable it to question and scrutinise government more effectively, he would likely face difficulties in Cabinet. Reformers thus looked to the new Leader of the House to deliver reform, but it was not clear that, even if he wanted to, he would be able to.

\section{The House of Lords}

The House of Commons is the elected, and thus the pre-eminent, chamber in Parliament. It pre-eminence is recognised in statute and also in constitutional convention: the House of Lords does not normally vote on the second reading (that is, on the principle) of a bill that was promised in the government's programme. By statute, it can only delay a Bill for one parliamentary session (that is, a year). The House is a non-elected chamber, hence its political subordination to the first. For most of its history, it has comprised mostly hereditary peers (plus some senior churchmen). Two major reforms in recent decades have transformed the composition of the House. The first of these was the Peerages Act 1958 which made provision for life peers to be created, the title dying out once the holder died. This made it possible to bring into the House of Lords people who objected to hereditary peerages (and hence would not accept such peerages) as well as making possible the creation of more members without adding to the numbers in the long term. When a life peer died, the membership of the House was reduced by one. When an hereditary peer died, there was usually no effect on the number of members, as the peer was succeeded as a member by his heir. The effect of life peerages was to bring in to the House more active members. The average attendance rose decade by decade and the House became a more active House, utilising more than before committees to carry out some of its work.

The second major reform came with the election of a Labour government in 1997. The Labour Party was opposed to the retention of hereditary peers in the second chamber. Some favoured an elected second chamber. Some actually preferred a unicameral legislature. However, the party moved from favouring abolition to supporting a second chamber but with the hereditary peers removed from membership. In its 1997 manifesto, it declared that, "as an initial, self-contained reform, not dependent on further reform in the future, the right of hereditary peers to sit and vote in the House of Lords will be ended by statute". That, it said, would be the first stage in a process of reform to make the House of Lords "more democratic and representative". A committee of both Houses would then be appointed

Revue Française de Civilisation Britannique, XI-3 | 2002 
to undertake "a wide-ranging review of possible further change and then to bring forward proposals for reform".

The government anticipated problems in getting the Bill through the House of Lords. Though the government knew it could ultimately get its way, it also knew that the Lords could cause problems during the passage of the Bill and, indeed, cause problems in dealing with other government Bills. The government therefore delayed introducing the Bill until the second session (1998-99) of the Parliament. It also agreed a deal with the Leader of the Conservative peers, Lord Cranborne, under which 92 hereditary peers (out of approximately 750) remained members of the House in return for the relatively smooth passage of the Bill. The deal was kept to by both sides and the Bill was enacted. When the House of Lords met for the new session in November 1999, it was a body reduced from a membership of just over 1,200 (the majority of them hereditary peers) to one of 666 (the majority of them life peers). Most members could thus claim to be there because of the recognition of their particular merits rather than the merits of their ancestors.

The House of Lords Act constituted the first stage of the government's two-stage approach to reform. However, the government was criticised for not saying what its plans were for the second stage. In response to this criticism, the government decided early in 1999 to appoint a Royal Commission on the Reform of the House of Lords to make recommendations for stage two. The Royal Commission, under a former Conservative minister, Lord Wakeham, was asked to report by the end of 1999, and it did so. The report, A House for the Future, made 132 proposals on recruitment and procedures.$^{19}$ It recommended a part-elected House of approximately 550 members, offering three options for the number to be elected (65, 87 or 195), most members of the Commission preferring 87. The Leader of the House of Lords, Baroness Jay, announced on 7 March 2000 that the government was minded to accept "the broad outlines" of the report. This stance was maintained by the government and in its manifesto for the 2001 general election it declared:

We are committed to completing House of Lords reform, including removal of the remaining hereditary peers, to make it more representative and democratic, while maintaining the House of Commons' traditional primacy. We have given our support to the report and conclusions of the Wakeham Commission and will seek to implement them in the most effective way possible. ${ }^{20}$

In the Queen's Speech at the opening of the Parliament, the government promised "following consultation" to introduce legislation to implement the second phase of House of Lords reform. It thus looked as if the new Parliament would witness the completion of a major transformation in the nature of the second chamber.

By 2001, the Labour government had thus achieved major change in the second chamber, an achievement that some critics had not thought possible. Others, however, called attention to the limits of the change. The House remained an appointed rather than an elected House. It was not in a position to challenge the supremacy of the elected House. Even if stage two reform was implemented, it would still be a predominantly appointed House. The government showed no appetite for a wholly elected House.

41 The limits of the reform were hardly surprising. Many, including the Royal Commission, recognised that the existing House had a number of merits. It was a House of experienced and often expert members who were able to subject legislation to informed scrutiny in a way that the House of Commons could not. The scrutiny of European legislation by the 
House of Lords was widely recognised, not just in the UK but in the institutions of the European Union, as being authoritative and of high quality. The House added value to the political process and there was a reluctance to lose that value. Of the submissions received by the Royal Commission, those who were most informed about the work of the House were more likely than others who made submissions to support the retention of the House as an appointed chamber. There was also the recognition that the House of Commons (or, as some critics pointed out, primarily that part of the House of Commons which formed the government) was not going to be too keen on having an elected second chamber that would thus be in a position to challenge its own supremacy. The House of Commons was not expected to be willing to move from being the elected chamber to being one of two elected chambers.

At the start of the new Parliament in 2001, there was thus little prospect of anything more than a part-elected chamber being created. Indeed, some critics doubted if even a part-elected chamber would be achieved. The government had committed itself to legislation but only after "further consultation". It was known that the parties would not necessarily agree on what form the consultation should take. A joint committee had not been appointed at the end of the previous Parliament because of disagreement as to what it should do. There was the belief on the part of some observers that "further consultation" was a euphemism for taking things slowly or even making no progress at all. There was the prospect of a part-elected House, but that appeared to be the most that reformers could hope for, and even that was not certain.

\section{Conclusion}

The British Parliament has thus seen changes to both Houses since the election of a Labour government in 1997. The institution looks very different to that which existed in 1997 and it operates in a notably changed constitutional framework. However, the changes in many respects are as remarkable for how far they have failed to go as for how far they have actually gone. Reform of the House of Commons has fallen far short of what reformers have advocated. It has seen little, if any, increase in its viscosity. The stream has got stronger as its capacity to limit it has changed very little. Reform of the House of Lords has not gone as far as some reformers wished, though admittedly much further than some Conservatives want. Further change to the both Houses is on the political agenda. Some of these changes may be realised but there are countervailing forces at work that may well ensure that completion of a reform agenda is partial rather than full.

\section{NOTES}

1. Michael MEZEY, Comparative Legislatures, Durham NC: Duke University Press, 1979. Philip NORTON, "Parliament and Policy in Britain: The House of Commons as a Policy Influencer", Teaching Politics, vol. 13, 1984, pp. 198-202, reproduced in Philip Norton (ed.), Legislatures, Oxford: Oxford University Press, 1990, pp. 177-80. 
2. Jean BLONDEL et al., "Legislative Behaviour: Some Steps towards a Cross-National Measurement", Government and Opposition, vol. 5, 1970, pp. 67-85.

3. The Commission to Strengthen Parliament, Strengthening Parliament, London: The Conservative Party, 2000.

4. The Labour Party, New Labour: because Britain deserves better, London: The Labour Party, 1997, p. 33.

5. The Legislative Process, First Report from the Select Committee on the Modernisation of the House of Commons, Session 1997-98, HC 190.

6. House of Commons Debates: Official Report (Hansard), Volume 353, column 1059, 13 July 2000.

7. Peter RIDDELL, Parliament Under Blair, London: Politico's, 2000, p. 245.

8. Philip NORTON, “Parliament", in Anthony SELDON (ed.), The Blair Effect, London: Little, Brown, 2001.

9. P. DUNLEAVY and G. W. JONES, "Leaders, Politics and Institutional Change: The Decline of Prime Ministerial Accountability in the House of Commons, 1868-1990", British Journal of Political Science, vol. 23, 1993, pp. 267-98.

10. Andrew TYRIE, Mr Blair's Poodle, London: The Centre for Policy Studies, 2000, pp. 29-30.

11. House of Commons Debates: Official Report (Hansard), vol. 353, column 1097, 13 July 2001.

12. Shifting the Balance: Select Committees and the Executive, First Report from the Liaison Select Committee, Session 1999-2000, HC 300.

13. The Commission to Strengthen Parliament, Strengthening Parliament, London: The Conservative Party, 2000.

14. Hansard Society, Making the Law: The Report of the Hansard Society Commission on the Legislative Process, London: The Hansard Society, 1993.

15. Hansard Society, The Challenge for Parliament: Making Government Accountable, London: Vacher Dod Publishing, 2001.

16. Hansard Society, The Challenge for Parliament: Making Government Accountable, London: Vacher Dod Publishing, 2001, Para. 8.67, p. 106.

17. The Labour Party, Ambitions for Britain, London: The Labour Party, 2001.

18. House of Commons Debates: Official Report (Hansard), vol. 370, column 738, 27 June 2001.

19. The Royal Commission on the Future of the House of Lords, A House for the Future, London: Her Majesty's Stationery Office, 2000, Cm 4534.

20. The Labour Party, Ambitions for Britain, London: The Labour Party, 2001.

\section{ABSTRACTS}

The key concept of any study of the role of Parliament focuses on the extent to which it is able to influence and constrain the Executive. Reforming Parliament should seek to strengthen its capacity to do so. A clear distinction ought to be drawn between external and internal reforms of the Parliamentary system. While the former strive to achieve the desired goal through changes in the constitutional framework - e.g. the reform of the House of Lords - the latter aim to improve the working of existing structures. As regards the House of Commons, it is questionable whether the internal reforms introduced by the Blair government actually met the demands of the advocates of the strengthening of Parliament. Indeed one may even argue that the lower 
House has become more marginalised while the uncompleted reform of the House of Lords has failed to clarify the future role of the second chamber.

L'analyse de la capacité du Parlement à peser sur le pouvoir de décision de l'exécutif est au centre de toute étude du dispositif institutionnel. La réforme du fonctionnement $\mathrm{du}$ système parlementaire doit avoir pour objectif le renforcement de ce rôle d'influenceur. Selon les cas, les réformes seront d'origine externe ou à caractère interne. Les premières procèdent d'une modification constitutionnelle ; tel est le cas notamment de la réforme de la Chambre des Lords. Les secondes visent à améliorer la qualité du travail parlementaire. S'agissant de la Chambre des Communes, on se demandera si les réformes internes mises en œuvre par le précédent gouvernement Blair ont répondu à l'attente des partisans du renforcement des pouvoirs du Parlement. On peut, du reste, aller jusqu'à affirmer que la Chambre Basse connaît aujourd'hui une marginalisation plus marquée. Quant à la Chambre Haute, seul l'achèvement de la réforme permettra d'en clarifier le rôle.

\section{AUTHOR}

\section{PHILIP NORTON}

[Lord Norton of Louth]

University of Hull 